\title{
Short communication: Effects of pregnancy on milk yield, composition traits, and coagulation properties of Holstein cows
}

\author{
M. Penasa, ${ }^{1}$ M. De Marchi, and M. Cassandro \\ Department of Agronomy, Food, Natural Resources, Animals and Environment, University of Padova, Viale dell'Università 16, \\ 35020 Legnaro (PD), Italy
}

\begin{abstract}
The aim of this study was to investigate the effect of pregnancy stage on milk yield, composition traits, and milk coagulation properties in Italian Holstein cattle. The data set included 25,729 records from 3,995 firstparity cows calving between August 2010 and August 2013 in 167 herds. The traits analyzed were milk yield $(\mathrm{kg} / \mathrm{d})$, fat $(\%)$, protein $(\%)$, casein $(\%)$, and lactose (\%) contents, $\mathrm{pH}$, somatic cell score, rennet coagulation time ( $\mathrm{min})$, and curd firmness $(\mathrm{mm})$. To better understand the effect of gestation on the aforementioned traits, each record was assigned to one of the following classes of pregnancy stage: (1) nonpregnant, (2) pregnant from 1 to $120 \mathrm{~d}$, (3) pregnant from 121 to $210 \mathrm{~d}$, and (4) pregnant from 211 to $310 \mathrm{~d}$. Gestation stage significantly influenced all studied traits with the exception of somatic cell score. Milk production decreased and milk quality improved from the fourth month of pregnancy onward. For all traits, nonpregnant cows performed very similarly to cows in the first period of gestation. Rennet coagulation time and curd firmness were influenced by pregnancy stage, especially in the last weeks of gestation when milk had better coagulation characteristics; this information should be accounted for to adjust test-day records in genetic evaluation of milk coagulation properties.
\end{abstract}

Key words: Holstein cow, mid-infrared spectroscopy, milk coagulation property, pregnancy

\section{Short Communication}

The amount of milk used for cheese production worldwide is growing (Pieri, 2014). Therefore, it is important to evaluate some aspects of milk destined for the cheese industry, especially those related to technological quality. Several factors contribute to define milk quality and among them milk coagulation properties (MCP) are of

Received July 24, 2015.

Accepted February 21, 2016.

${ }^{1}$ Corresponding author: mauro.penasa@unipd.it particular interest because they affect the efficiency of the cheese-making process (Bynum and Olson, 1982; Pretto et al., 2013).

Traditionally, MCP have been recorded using mechanical systems that provide measures of milk clotting ability, the most common being rennet coagulation time $\left(\mathbf{R C T}\right.$, min) and curd firmness $\left(\mathbf{a}_{\mathbf{3 0}}, \mathbf{m m}\right)$. The first trait defines the interval from the addition of rennet to milk to the start of gel formation, and the second measures the firmness of the coagulum $30 \mathrm{~min}$ after rennet addition (Annibaldi et al., 1977; McMahon and Brown, 1982). Besides mechanical devices, many other techniques are used to determine MCP (O'Callaghan et al., 2002); among them, mid-infrared spectroscopy is very popular in the dairy industry for rapid and cheap collection of milk phenotypes (De Marchi et al., 2014).

Pregnancy is responsible for a decline in milk yield (MY), particularly after mo 4 or 5 of gestation, when a significant amount of nutrients available in the blood of the cow is destined to the growth and maintenance of the developing fetus (e.g., Ragsdale et al., 1924; Olori et al., 1997; Leclerc et al., 2008). There is broad consensus that the physiological mechanisms by which gestation negatively affects MY in the last part of the lactation are mainly related to hormone-mediated partitioning of nutrients from milk production to pregnancy requirements (Oltenacu et al., 1980). Gestation stage also affects milk composition, particularly fat and protein percentages. Overall, these milk constituents increase as pregnancy advances, especially after the fourth month of gestation (Parkhie et al., 1966; Rodriguez et al., 1985; Olori et al., 1997). The effect of pregnancy on milk, fat, and protein yields has been widely investigated and is currently accounted for in the genetic evaluation of bulls and cows in different countries (including Italy) to adjust test-day milk production records (Interbull, 2015). Conversely, very few studies have dealt with the effect of gestation on milk constituents, and there is a lack of knowledge on the influence of gestation on MCP. Therefore, the aim of this work was to estimate the effects of pregnancy on test-day MY, composition traits (fat, protein, casein, 
and lactose percentages), $\mathrm{pH}, \mathrm{SCS}$, and MCP in firstlactation Holstein cows. The existence of a gestation effect on aforementioned traits would support the need to incorporate it in genetic evaluation models to avoid penalizing pregnant cows.

Records on daily milk yield, fat, protein, casein and lactose contents, $\mathrm{pH}, \mathrm{SCC}$, and coagulation properties (RCT and $\mathrm{a}_{30}$ ) of first-parity Italian Holstein cows calving for the first time between 20 and 40 mo of age were provided by the Breeders Association of Veneto region (Padova, Italy). All herds were enrolled in official monthly test-day milk recording and cows were milked twice daily. Milk samples were analyzed in the laboratory of the Breeders Association of Veneto region using Milko-Scan FT6000 (Foss, Hillerød, Denmark). Milk coagulation properties were predicted using midinfrared spectroscopy models developed by De Marchi et al. $(2012,2013)$.

Data were edited to remove cows without information on the subsequent calving date. Days in milk were restricted to be between 5 and 450, MY between 2 and $80 \mathrm{~kg} / \mathrm{d}$, fat content between 1.5 and $9 \%$, protein content between 1 and $7 \%$, casein content between 1 and $4 \%$, lactose content $>3.80 \%$, SCC $<10,000,000$ cells/ $\mathrm{mL}, \mathrm{pH}$ between 6.40 and 6.85 , RCT between 5 and 30 min and $\mathrm{a}_{30}<60 \mathrm{~mm}$. For each test-date, values of SCC were log-transformed to SCS to achieve normality and homogeneity of variances according to the formula SCS $=3+\log _{2}(\mathrm{SCC} / 100,000)$. Cows were retained if they produced all their records within the same herd and if they had at least 5 observations within the lactation. Contemporary groups were defined as cows sampled in the same herd-test-date (HTD), and HTD with fewer than 5 cows were removed from the data set.

Calving interval was computed as the number of days between the first and the second calving date, and days open (DO) were determined as follows: (1) if AI data were available, DO were calculated as the number of days between the last insemination (assumed as the insemination of success) and first calving date; (2) if AI data were not available, DO were estimated as calving interval minus an assumed gestation length (GL) of 280 d (Norman et al., 2009; Bastin et al., 2012). If AI data were available, GL was calculated by subtracting DO from calving interval, and only cows with GL between 210 and $310 \mathrm{~d}$ were retained. Days open $<21$ were deleted from the data set, and DO $>365$ were set to 365, as in Bastin et al. (2012). For each testdate record, days carried calf was calculated as DIM of the cow minus DO: if the difference was $<0$, the cow was identified as nonpregnant; otherwise, the cow was pregnant.
After editing, the final data set included 25,729 records of MY, composition traits, pH, SCS, and coagulation properties, and 3,995 calving interval and DO records from 3,995 first-parity cows calving between August 2010 and August 2013 in 167 herds. Based on days carried calf, as calculated as above, each record of MY, composition traits, $\mathrm{pH}$, SCS, and MCP was assigned to one of the following classes of pregnancy stage, as in the approach of Parkhie et al. (1966): (1) nonpregnant $(\mathrm{n}=8,742)$; (2) pregnant from 1 to 120 $\mathrm{d}(\mathrm{n}=10,111) ;(3)$ pregnant from 121 to $210 \mathrm{~d}(\mathrm{n}=$ $5,959)$; and (4) pregnant from 211 to $310 \mathrm{~d}(\mathrm{n}=917)$. The average number of records per cow was 6.4 (range: 5 to 13 ) and the average number of cows sampled per herd in the period of the study was 24 (range: 5 to 200). Finally, the average number of cows sampled in the same HTD was 14 (range: 5 to 97 ).

Sources of variation of MY, composition traits, $\mathrm{pH}$, SCS, and MCP were investigated using the following linear mixed model (SAS Institute Inc., Cary, NC):

$$
\begin{aligned}
\mathrm{y}_{i j k l m}=\mu+ & \mathrm{HTD}_{i}+\mathrm{AGE}_{j}+\mathrm{SL}_{k}+\mathrm{PS}_{l} \\
& +\operatorname{cow}_{m}+\mathrm{e}_{i j k l m},
\end{aligned}
$$

where $\mathrm{y}_{i j k l m}$ is the dependent variable (MY, fat, protein, casein, or lactose content, $\mathrm{pH}, \mathrm{SCS}, \mathrm{RCT}$, or $\left.\mathrm{a}_{30}\right) ; \mu$ is the overall intercept of the model; $\mathrm{HTD}_{i}$ is the fixed effect of the $i$ th herd-test-date $(i=1$ to 1,788$) ; \mathrm{AGE}_{j}$ is the fixed effect of the $j$ th class of age at calving of the cow $(j=1$ to 12 , with the first being a class from 20 to 22 mo, followed by 9 monthly classes, the second to last being a class from 32 to $33 \mathrm{mo}$, and the last being a class $>33 \mathrm{mo}$ ); $\mathrm{SL}_{k}$ is the fixed effect of the $k$ th class of stage of lactation of the cow $(k=1$ to 12 , with the first 10 being monthly classes, the second to last being a class from 306 to $350 \mathrm{~d}$, and the last being a class $>350$ d); $\mathrm{PS}_{l}$ is the fixed effect of the $l$ th class of pregnancy stage of the cow ( $l=1$ to 4 , as previously described); $\mathrm{cow}_{m}$ is the random effect of the $m$ th cow $(m=1$ to $3,995) \sim N\left(0, \sigma_{\text {cow }}^{2}\right) ; \mathrm{e}_{i j k l m}$ is the random residual $\sim N\left(0, \sigma_{e}^{2}\right)$. The distribution of records across classes of lactation and pregnancy stages is reported in Table 1.

Descriptive statistics of MY and fat and protein contents (Table 2) were very similar to national data reported by the Italian Breeders Association (AIA, 2013) for the first-parity Holstein population. Average MY was $25.4 \mathrm{~kg} / \mathrm{d}$ for first-lactation Canadian Holsteins (Bohmanova et al., 2009), which is $3 \mathrm{~kg}$ less than the mean value of the present work. However, the study of Bohmanova et al. (2009) included test-day records from animals that calved from 1988 to 2006, and it is 
PENASA ET AL.

Table 1. Number of records across lactation and gestation stages

\begin{tabular}{lcccc}
\hline & \multicolumn{4}{c}{ Pregnancy stage } \\
\cline { 2 - 5 } Stage of lactation, d & Nonpregnant & 1 to $120 \mathrm{~d}$ & 121 to $210 \mathrm{~d}$ & 211 to $310 \mathrm{~d}$ \\
\hline 5 to 35 & 1,739 & 5 & 0 & 0 \\
36 to 65 & 1,870 & 192 & 0 & 0 \\
66 to 95 & 1,397 & 651 & 0 & 0 \\
96 to 125 & 1,073 & 1,090 & 0 & 0 \\
126 to 155 & 786 & 1,450 & 170 & 0 \\
156 to 185 & 610 & 1,571 & 563 & 0 \\
186 to 215 & 454 & 1,259 & 917 & 112 \\
216 to 245 & 322 & 1,017 & 1,135 & 201 \\
246 to 275 & 232 & 786 & 892 & 258 \\
276 to 305 & 144 & 681 & 1,064 & 344 \\
306 to 350 & 101 & 741 & 1,218 & 0 \\
$>350$ & 14 & 668 & & \\
\hline
\end{tabular}

expected that cows from the initial period of the study produced significantly less milk than those of the last period. The mean value for $\mathrm{a}_{30}$ (Table 2 ) was $3.2,4.1$, and $3.9 \mathrm{~mm}$ greater than values of Tiezzi et al. (2013), Penasa et al. (2014), and Varotto et al. (2015), respectively, and average RCT was very similar to values reported in the aforementioned studies. Herd-test-date and stage of lactation effects were highly significant $(P$ $<0.001$ ) in explaining the variability of MY, composition traits, $\mathrm{pH}, \mathrm{SCS}$, and MCP. Age at calving affected only MY and lactose content $(P<0.01)$, and pregnancy stage was significant $(P<0.001)$ for all traits except for SCS (Table 3). In the present study, the interaction effect between lactation and pregnancy stage could not be investigated because of the scarcity or absence of records in some classes of the interaction (Table 1). This could have led to a partial confounding between stage of lactation and gestation period even if their in- clusion as main effects should have partially mitigated the confounding.

Pregnancy stage was introduced as a categorical explanatory variable in the statistical analysis of studied traits. A similar approach was followed by Parkhie et al. (1966), who classified gestation of Holstein cows into 4 periods and investigated its effect on milk constituents. Loker et al. (2009) estimated the effect of pregnancy on milk production traits of dairy cattle breeds by means of 4 different models and concluded that the approach based on the use of stage of pregnancy classes provided the most realistic and practical estimate of the effect of carrying the calf on milk, fat, and protein yields. Testday records of cows analyzed by Loker et al. (2009) were grouped in 8 classes of days pregnant, whereas we grouped data into 4 classes. The choice of grouping records into fewer classes compared with that in Loker et al. (2009) was a consequence of the much smaller

Table 2. Descriptive statistics of milk yield, composition traits, pH, SCS, coagulation properties, and functional traits

\begin{tabular}{|c|c|c|c|c|c|}
\hline Trait & No. & Mean & $\mathrm{CV}, \%$ & Minimum & Maximum \\
\hline DIM & 25,729 & 193 & 56.4 & 5 & 450 \\
\hline \multicolumn{6}{|l|}{ Milk composition traits } \\
\hline Protein, \% & 25,729 & 3.42 & 10.9 & 2.11 & 5.17 \\
\hline Casein, \% & 25,729 & 2.68 & 11.6 & 1.46 & 3.99 \\
\hline Lactose, \% & 25,729 & 4.90 & 3.4 & 3.82 & 5.46 \\
\hline \multicolumn{6}{|c|}{ Milk coagulation properties ${ }^{1}$} \\
\hline $\mathrm{RCT}, \min$ & 25,729 & 20.8 & 20.1 & 5.0 & 29.9 \\
\hline $\mathrm{a}_{30}, \mathrm{~mm}$ & 25,729 & 24.9 & 38.8 & 0.2 & 59.8 \\
\hline \multicolumn{6}{|l|}{ Functional traits } \\
\hline Age at calving, mo & 3,995 & 26.7 & 12.1 & 20 & 40 \\
\hline Calving interval, $\mathrm{d}$ & 3,995 & 429 & 19.1 & 302 & 674 \\
\hline Days open, d & 3,995 & 148 & 54.9 & 22 & 365 \\
\hline
\end{tabular}

${ }^{1} \mathrm{RCT}=$ rennet coagulation time; $\mathrm{a}_{30}=$ curd firmness. 
Table 3. F-value and significance of fixed effects ${ }^{1}$ included in the analysis for milk yield, composition traits, pH, SCS, and coagulation properties

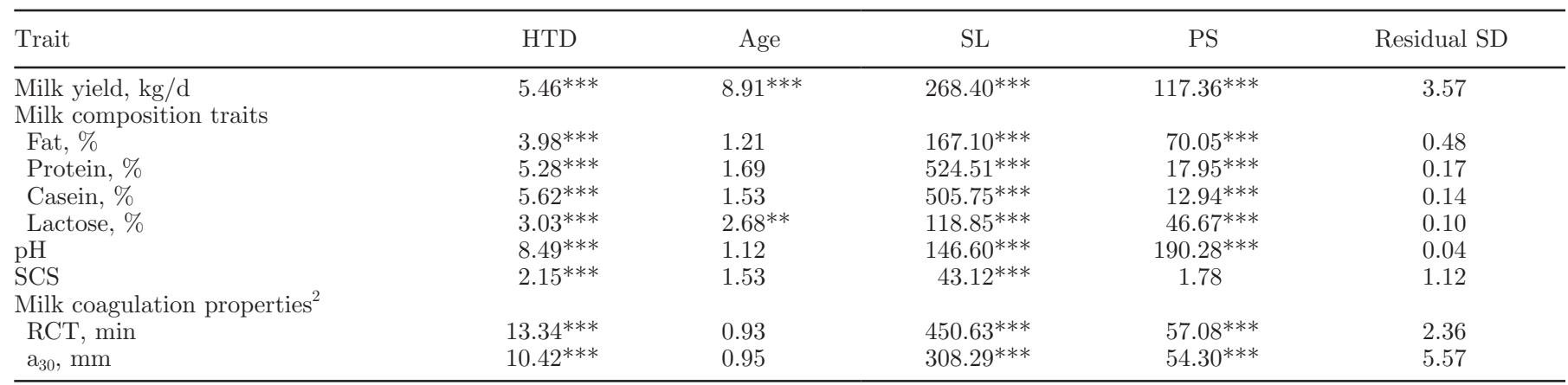

${ }^{1} \mathrm{HTD}=$ herd-test-date; Age = age at calving; $\mathrm{SL}=$ stage of lactation; PS = pregnancy stage.

${ }^{2} \mathrm{RCT}=$ rennet coagulation time; $\mathrm{a}_{30}=$ curd firmness .

${ }^{* *} P<0.01 ;{ }^{* * *} P<0.001$.

number of test-day records available in the present study and the need to reach good representativeness of the classes, especially from $210 \mathrm{~d}$ of pregnancy onward.

Milk yield of nonpregnant cows did not differ $(P>$ 0.05 ) from that of cows within the first 4 mo of pregnancy, whereas milk production decreased significantly $(P<0.05)$ from mo 4 onward (Table 4$)$. In particular, animals between 1 and $120 \mathrm{~d}$ pregnant produced 0.9 and $3.1 \mathrm{~kg} / \mathrm{d}$ more milk than animals between 121 and $210 \mathrm{~d}$, and those between 211 and $310 \mathrm{~d}$ pregnant, respectively. The negative effect of carrying the calf on production, especially from mo 4 or 5 gestation, has been reported by several authors (e.g., Brotherstone et al., 2004; Leclerc et al., 2008; Bohmanova et al., 2009) and it has been mainly attributed to hormonal changes in the maternal organism during gestation (Bauman and Currie, 1980; Oltenacu et al., 1980). Endocrine changes affect the partitioning of energy and protein away from milk synthesis and in favor of fetus growth and the replenishment of body reserves for subsequent lactation (Oltenacu et al., 1980). In particular, Bauman and Currie (1980) reported that nutrient requirements of a cow at the end of gestation are about $75 \%$ greater than those of a nonpregnant animal of the same weight.

Milk fat content differed significantly $(P<0.05)$ across stage of pregnancy classes (Table 4 ). In particular, cows after mo 7 of gestation produced milk with a much greater fat content $(4.03 \%)$ compared with animals between 1 and $120 \mathrm{~d}(3.77 \%)$ and 121 to $210 \mathrm{~d}$ $(3.88 \%)$ pregnant. Rodriquez et al. (1985) reported that fat percentage of milk from Holstein and Jersey breeds increased as gestation advanced, supporting findings of the present study. Olori et al. (1997) noted that fat content increased significantly from mo 6 gestation in first-parity Holstein dairy cattle. Protein and casein contents increased slightly but significantly $(P<0.05)$ across gestation (Table 4). Nonpregnant cows exhibited the lowest values of protein $(3.40 \%)$ and casein $(2.67 \%)$, and animals in the last period of pregnancy exhibited the greatest estimates (3.47 and $2.72 \%$, respectively).

Table 4. Least squares means (SE in parentheses) of milk yield, composition traits, pH, SCS, and coagulation properties across classes of pregnancy stage

\begin{tabular}{|c|c|c|c|c|}
\hline \multirow[b]{2}{*}{ Trait } & \multicolumn{4}{|c|}{ Pregnancy stage } \\
\hline & Nonpregnant & 1 to $120 \mathrm{~d}$ & 121 to $210 \mathrm{~d}$ & 211 to $310 \mathrm{~d}$ \\
\hline Milk yield, $\mathrm{kg} / \mathrm{d}$ & $28.5(0.11)^{\mathrm{a}}$ & $28.3(0.09)^{\mathrm{a}}$ & $27.4(0.11)^{\mathrm{b}}$ & $25.2(0.18)^{\mathrm{c}}$ \\
\hline \multicolumn{5}{|l|}{ Milk composition traits } \\
\hline Fat, $\%$ & $3.83(0.01)^{\mathrm{a}}$ & $3.77(0.01)^{\mathrm{b}}$ & $3.88(0.01)^{\mathrm{c}}$ & $4.03(0.02)^{\mathrm{d}}$ \\
\hline Protein, $\%$ & $3.40(0.01)^{\mathrm{a}}$ & $3.42(0.01)^{\mathrm{b}}$ & $3.43(0.01)^{\mathrm{c}}$ & $3.47(0.01)^{\mathrm{d}}$ \\
\hline Casein, \% & $2.67(0.01)^{\mathrm{a}}$ & $2.68(0.01)^{\mathrm{b}}$ & $2.69(0.01)^{\mathrm{c}}$ & $2.72(0.01)^{\mathrm{d}}$ \\
\hline Lactose, \% & $4.90(0.01)^{\mathrm{a}}$ & $4.89(0.01)^{\mathrm{b}}$ & $4.91(0.01)^{\mathrm{c}}$ & $4.91(0.01)^{\mathrm{ac}}$ \\
\hline $\mathrm{pH}$ & $6.62(0.01)^{\mathrm{a}}$ & $6.61(0.01)^{\mathrm{b}}$ & $6.63(0.01)^{\mathrm{c}}$ & $6.65(0.01)^{\mathrm{d}}$ \\
\hline SCS & $2.54(0.03)^{\mathrm{a}}$ & $2.50(0.03)^{\mathrm{a}}$ & $2.48(0.03)^{\mathrm{a}}$ & $2.55(0.05)^{\mathrm{a}}$ \\
\hline \multicolumn{5}{|c|}{ Milk coagulation properties ${ }^{1}$} \\
\hline $\mathrm{RCT}, \min$ & $21.2(0.07)^{\mathrm{a}}$ & $21.0(0.06)^{\mathrm{b}}$ & $20.4(0.07)^{\mathrm{c}}$ & $19.7(0.12)^{\mathrm{d}}$ \\
\hline $\mathrm{a}_{30}, \mathrm{~mm}$ & $24.1(0.16)^{\mathrm{a}}$ & $24.7(0.13)^{\mathrm{b}}$ & $26.0(0.17)^{\mathrm{c}}$ & $27.7(0.28)^{\mathrm{d}}$ \\
\hline
\end{tabular}


Results for protein percentage were in agreement with findings of Parkhie et al. (1966), who observed that cows pregnant for 7 mo or longer produced milk significantly higher in protein than cows pregnant for shorter periods. Olori et al. (1997) estimated a small increase of protein content after $7 \mathrm{mo}$ of pregnancy, and Rodriquez et al. (1985) and Roche (2003) observed an increase of protein content after mo 4 and mo 2 of gestation, respectively. The increase in estrogen level in maternal circulation during the last weeks of pregnancy (and its depression effect on MY) is suggested as a possible explanation for the increase in percentages of protein and other solids of milk as the gestation advanced (Hutton, 1958; Parkhie et al., 1966). No information on the effect of pregnancy on casein content could be retrieved from the literature, and therefore comparisons with the present study were not possible. Changes in lactose content across gestation were very small (Table 4 ), in agreement with Olori et al. (1997). Roche (2003) estimated an increase of lactose percentage starting from about 3 mo of pregnancy.

Milk $\mathrm{pH}$ increased slightly but significantly $(P<$ 0.05) from the first to the last period of gestation, whereas SCS did not differ $(P>0.05)$ across pregnancy stages (Table 4). However, the highest value of SCS was detected after mo 7. Results for $\mathrm{pH}$ indicated that milk from cows in the last weeks of gestation was somewhat less acidic than milk of cows in the first months of pregnancy. Rodriquez et al. (1985) reported that milk acidity increased to mo 4 of gestation and gradually decreased thereafter. Regarding SCS, Bohmanova et al. (2009) calculated slightly higher values in the last weeks of gestation compared with previous months, similar to findings of the present study.

Overall, MCP improved $(P<0.05)$ from the beginning to the end of gestation, and the effect of pregnancy was stronger on $\mathrm{a}_{30}$ than on RCT (Table 4). Rennet coagulation time and $\mathrm{a}_{30}$ had an opposite trend: $\mathrm{RCT}$ decreased by $1.3 \mathrm{~min}$ and $\mathrm{a}_{30}$ increased by $3 \mathrm{~mm}$ from the first to the last period of pregnancy. Milk of nonpregnant cows coagulated $0.2,0.8$, and 1.5 min later $(P$ $<0.05)$ and showed lower values of $\mathrm{a}_{30}$ by $0.6,1.9$, and $3.6 \mathrm{~mm}(P<0.05)$ compared with milk of pregnant cows from 1 to $120 \mathrm{~d}, 121$ to $210 \mathrm{~d}$, and 211 to $310 \mathrm{~d}$, respectively. No studies have dealt with the effect of pregnancy on MCP and thus the present results could not be compared with the literature. However, we can speculate that better values of MCP at the end of gestation could be partly due to higher content of milk solids.

In conclusion, pregnancy was shown to exert a significant effect on MY, fat, protein, casein, and lactose contents, $\mathrm{pH}$, and MCP of first-parity Italian Holstein cows, especially in the last weeks of gestation. Milk yield decreased during pregnancy, whereas milk composition traits improved. Rennet coagulation time and $a_{30}$ were influenced by pregnancy stage: cows in the last period of gestation produced milk with shorter $\mathrm{RCT}$ and firmer curd than cows at the beginning of gestation. Results of the present study suggest that the effect of pregnancy should be considered to adjust records of MCP in genetic evaluation of dairy cattle for $\mathrm{RCT}$ and $\mathrm{a}_{30}$. Further research should investigate the effect of pregnancy on other milk technological traits such as mineral composition.

\section{ACKNOWLEDGMENTS}

The authors thank Alice Bonomo (University of Padova, Italy) for valuable insights into the manuscript. The Breeders Association of Veneto region (Padova, Italy) is gratefully acknowledged for providing data used in this work. M. Penasa performed statistical analysis and wrote the first draft of the manuscript. M. De Marchi reviewed the paper. M. Cassandro conceived the hypothesis of the study and reviewed the manuscript. All authors contributed to the interpretation and discussion of the results, and approved the final version of the paper.

\section{REFERENCES}

AIA (Italian Breeders Association). 2013. Milk recording activity: Official statistics. Italian Breeders Association, Rome, Italy.

Annibaldi, S., G. Ferrari, and R. Mora. 1977. Nuovi orientamenti nella valutazione tecnica del latte: Tipizzazione lattodinamografica. Sci. Tecn. Latt. Cas. 28:115-126.

Bastin, C., D. P. Berry, H. Soyeurt, and N. Gengler. 2012. Genetic correlations of days open with production traits and contents in milk ok major fatty acids predicted by mid-infrared spectrometry. J. Dairy Sci. 95:6113-6121.

Bauman, D. E., and W. B. Currie. 1980. Partitioning of nutrients during pregnancy and lactation: A review of mechanisms involving homeostasis and homeorhesis. J. Dairy Sci. 63:1514-1529.

Bohmanova, J., J. Jamrozik, and F. Miglior. 2009. Effect of pregnancy on production traits of Canadian Holstein cows. J. Dairy Sci. 92:2947-2959.

Brotherstone, S., R. Thompson, and I. M. S. White. 2004. Effects of pregnancy on daily milk yield of Holstein-Friesian dairy cattle. Livest. Prod. Sci. 87:265-269.

Bynum, D. G., and N. F. Olson. 1982. Standardization of a device to measure firmness of curd during clotting of milk. J. Dairy Sci. 65:1321-1324.

De Marchi, M., M. Penasa, F. Tiezzi, V. Toffanin, and M. Cassandro. 2012. Prediction of milk coagulation properties by Fourier transform mid-infrared spectroscopy (FTMIR) for genetic purposes, herd management and dairy profitability. ICAR Technical Series 16:47-53. http://www.icar.org/wp-content/uploads/2015/09/tec_ series_16_Cork.pdf.

De Marchi, M., V. Toffanin, M. Cassandro, and M. Penasa. 2013. Prediction of coagulating and noncoagulating milk samples using mid-infrared spectroscopy. J. Dairy Sci. 96:4707-4715.

De Marchi, M., V. Toffanin, M. Cassandro, and M. Penasa. 2014. Invited review: Mid-infrared spectroscopy as phenotyping tool for milk traits. J. Dairy Sci. 97:1171-1186. 
Hutton, J. B. 1958. Oestrogen function in established lactation in the cow. J. Endocrinol. 17:121-133.

Interbull. 2015. National genetic evaluation forms provided by countries. Accessed Nov. 12, 2015. http://www.interbull.org/ib/ geforms.

Leclerc, H., D. Duclos, A. Barbat, T. Druet, and V. Ducrocq. 2008. Environmental effects on lactation curves included in a test-day model genetic evaluation. Animal 2:344-353.

Loker, S., F. Miglior, J. Bohmanova, J. Jamrozik, and L. R. Schaeffer. 2009. Phenotypic analysis of pregnancy effect on milk, fat, and protein yields of Canadian Ayrshire, Jersey, Brown Swiss, and Guernsey breeds. J. Dairy Sci. 92:1300-1312.

McMahon, D. J., and R. J. Brown. 1982. Evaluation of Formagraph for comparing rennet solutions. J. Dairy Sci. 65:1639-1642.

Norman, H. D., J. R. Wright, M. T. Kuhn, S. M. Hubbard, J. B. Cole, and P. M. VanRaden. 2009. Genetic and environmental factors that affect gestation length in dairy cattle. J. Dairy Sci. 92:22592269.

O'Callaghan, D. J., C. P. O'Donnell, and F. A. Payne. 2002. Review of systems for monitoring curd setting during cheesemaking. Int. J. Dairy Technol. 55:65-74.

Olori, V. E., S. Brotherstone, W. G. Hill, and B. J. McGuirk. 1997. Effect of gestation stage on milk yield and composition in Holstein Friesian dairy cattle. Livest. Prod. Sci. 52:167-176.

Oltenacu, P. A., T. R. Rounsaville, R. A. Milligan, and R. L. Hintz. 1980. Relationship between days open and cumulative milk yield at various intervals from parturition for high and low producing cows. J. Dairy Sci. 63:1317-1327.

Parkhie, M. R., L. O. Gilmore, and N. S. Fechheimer. 1966. Effect of successive lactations, gestation, and season of calving on constituents of cows' milk. J. Dairy Sci. 49:1410-1415.
Penasa, M., F. Tiezzi, A. Sturaro, M. Cassandro, and M. De Marchi. 2014. A comparison of the predicted coagulation characteristics and composition of milk from multi-breed herds of Holstein-Friesian, Brown Swiss and Simmental cows. Int. Dairy J. 35:6-10.

Pieri, R. 2014. Il Mercato del Latte-Rapporto 2013. Franco Angeli, Milan, Italy.

Pretto, D., M. De Marchi, M. Penasa, and M. Cassandro. 2013. Effect of milk composition and coagulation traits on Grana Padano cheese yield under field conditions. J. Dairy Res. 80:1-5.

Ragsdale, A. C., C. W. Turner, and S. Brody. 1924. The effect of gestation upon lactation in the dairy cow. J. Dairy Sci. 7:24-30.

Roche, J. R. 2003. Effect of pregnancy on milk production and bodyweight from identical twin study. J. Dairy Sci. 86:777-783.

Rodriquez, L. A., G. Mekonnen, C. J. Wilcox, F. G. Martin, and W. A. Krienke. 1985. Effects of relative humidity, maximum and minimum temperature, pregnancy, and stage of lactation on milk composition and yield. J. Dairy Sci. 68:973-978

Tiezzi, F., D. Pretto, M. De Marchi, M. Penasa, and M. Cassandro. 2013. Heritability and repeatability of milk coagulation properties predicted by mid-infrared spectroscopy during routine data recording, and their relationships with milk yield and quality traits. Animal 7:1592-1599.

Varotto, A., M. De Marchi, M. Penasa, and M. Cassandro. 2015. A comparison of milk clotting characteristics and quality traits of Rendena and Holstein-Friesian cows. Ital. J. Anim. Sci. 14:202206 